\title{
CAN PICTURES HAVE EXPLICATURES?
}

\author{
Charles Forceville* \\ Universiteit van Amsterdam \\ Amsterdam, Netherlands
}

\author{
Billy Clark** \\ Middlesex University \\ London, England
}

\begin{abstract}
This paper considers the question of whether pictures can be understood to give rise to explicit meanings. In relevance-theoretic terms, this means asking whether pictures give rise to 'explicatures'. The definition of the term 'explicature' seems to rule out this possibility except in cases where pictures include or are accompanied by material with coded meanings. The paper considers a range of non-verbal phenomena with coded meanings, including pictograms (FORCEVILLE 2011, FORCEVILLE et al 2014). It then considers whether the explicature-implicature distinction could be relevant to pictures without such elements. Some assumptions communicated by pictures seem to be more 'explicature-like' than others, so it is possible that the distinction will be useful. The question is not merely terminological as the discussion leads to a fuller understanding of ways in which pictures communicate.
\end{abstract}

Keywords: Relevance theory. Pictures. Explicature. Pictorial codes. Visual communication. Multimodality.

\section{INTRODUCTION1}

Ostensive communication often involves pictures, especially in mass communication. While Sperber and Wilson's relevance theory (1995 [1986]) aims to account for all ostensive communication, the majority of work in this and other approaches has focused on spoken verbal communication. Wharton (2009) develops an account of nonverbal behaviours in general and Forceville has developed an account of how pictures are understood (see, for example, FORCEVILLE, 1996, 2005, 2009, 2014, see also YUS, 2008, 2009). There is still considerable work to be done in developing a systematic account of how pictures are understood. In this paper we discuss one element which will contribute to this account, namely the question of whether ostensive pictures (understood as images created with the intention to communicate) can be said to have explicit meaning. Within relevance theory (SPERBER; WILSON, 1995 [1986]; see also

\footnotetext{
* Associate professor at Universiteit van Amsterdam. $\mathrm{PhD}$ in Media Studies, Vrije Universiteit, Amsterdam. E-mail: c.j.forceville@uva.nl.

** Reader at Middlesex University, London. PhD in Linguistics, University College London. E-mail: b.clark@mdx.ac.uk.

${ }^{1}$ We are grateful to Tim Wharton and Francisco Yus for helpful comments and suggestions. Of course, we are fully responsible for all errors.
} 
WILSON; SPERBER, 2012, CLARK, 2013) this amounts to asking whether pictures can be said to give rise to 'explicatures'. Explicatures are communicated assumptions recovered on the basis of pragmatic inference fleshing out encoded meanings. No other variety of explicit meaning is recognised within relevance theory. If we assume that the 'encoded meanings' referred to here are linguistically encoded, it may seem instantly clear that the answer to this question must be either 'no' or 'only where pictures include linguistic material'. Nevertheless, we believe that it is worth asking whether pictures can have explicatures for three reasons. First, there are encoded meanings which are not linguistic, including coded elements of nonverbal communication (discussed, for example, by WHARTON, 2009) and coded pictorial meanings such as the 'pictograms' discussed by Forceville (2011; see also FORCEVILLE et al, 2014). Whether or not to extend the range of the term 'explicature' to these phenomena is largely a terminological question. A key question in answering this is how similar the codes involved are to linguistic encoding/decoding. Second, some of the other ways in which pictures convey meanings seem to be closer to explicatures than others, suggesting that something along the lines of the explicature-implicature distinction could be useful in analysing pictures. Finally, we think that exploring this question will make a significant contribution to understanding how ostensive pictures are produced and understood.

In section 2, we present the relevance-theoretic notion of explicature, making clear why this definition suggests that pictures will give rise to explicatures only where they include linguistic material. In section 3, we consider two kinds of coded communication which can appear non-linguistically: first, based largely on the work of Wharton (2009), we consider nonverbal communication in general; second, based on the work of Forceville (2011, FORCEVILLE et al, 2014) we consider pictorial codes. Many cases of nonverbal communication fit the default assumption that all the propositions they communicate are implicatures. However, some nonverbal meanings involve coded meanings and thus give rise to explicatures. This section discusses several instances and so extends the range of things which we might describe as explicatures when considering ostensive pictures. In section 4 , we consider elements of pictures which do not involve coding and consider the extent to which the conclusions inferred seem to fit the definition of explicatures (i.e. to be inferred by fleshing out coded meanings) and the extent to which they seem to fit the definition of implicatures (i.e. to be inferred in any other way). We do not propose at this stage to extend the reach of the term 'explicature' to include conclusions inferred from purely visual material, leaving that question as one to be resolved in future work (in this respect we are here more cautious than FORCEVILLE, 2014). However, we do propose that distinctions can be made between 'explicature-like' assumptions, which in turn can be seen as further dividable into a number of subtypes, and implicatures. We close by considering a number of arguments for and against the view that pictures give rise to explicatures other than those developed from the three kinds of encoding discussed here. While we do not reach a definite conclusion, we suggest that this discussion leads to a fuller understanding of how pictures are understood as well as of the nature of ostensiveinferential communication more generally. 
In presenting an account of the distinction between explicature and implicature, Sperber and Wilson define explicitness as follows:

\title{
Explicitness
}

An assumption communicated by an utterance $U$ is explicit if and only if it is a development of a logical form encoded by U (SPERBER; WILSON, 1995 [1986], p. 182).

They go on to say:

\begin{abstract}
On the analogy of 'implicature', we will call an explicitly communicated assumption an explicature. Any assumption communicated, but not explicitly so, is implicitly communicated: it is an implicature. By this definition, ostensive stimuli which do not encode logical forms will, of course, only have implicatures. [...] An explicature is a combination of linguistically encoded and contextually inferred conceptual features. The smaller the relative contribution of the contextual features, the more explicit the explicature will be, and inversely. Explicitness, so understood is both classificatory and comparative: a communicated assumption is either an explicature or an implicature, but an explicature is explicit to a greater or lesser degree (SPERBER; WILSON, 1995 [1986], p. 182).
\end{abstract}

The authors point out that explicatures are only partly explicit and that significant pragmatic inferencing is required to recover them. For our purposes, two key things to notice are that 'ostensive stimuli which do not encode logical forms will ... only have implicatures' and that 'an explicature is explicit to a greater or lesser degree'. In this section, we begin by explaining the distinction between explicatures and implicatures, pointing out why this suggests that pictures cannot have explicatures, and then spell out some properties of both explicatures and implicatures. In particular, we consider two things which are matters of degree rather than constituting binary oppositions: the fact that explicatures can be more or less explicit and the fact that implicatures can be more or less strongly communicated. Both of these notions will be important in our discussion of pictures below.

\subsection{EXPLICATURES}

When first proposing the notion of explicature, the main focus of Sperber and Wilson's discussion, apart from replacing Grice's term 'what is said' with the new term 'explicature' (the term's ending being modelled on Grice's 'implicature') was to demonstrate two things which are now commonly assumed by many pragmatic theories: first, that there is more to recovering explicatures than Grice had envisaged; second, that pragmatic principles are involved in the recovery of explicit as well as implicit meaning. Explicatures are assumptions communicated partly explicitly. Implicatures are assumptions communicated implicitly (through the interaction of contextual assumptions and explicatures where there are any). We can illustrate this with the exchange in (1): 
(1) Andy: You not having milk in your coffee today?

Beth: It's off.

To understand what proposition Beth is expressing, Andy needs to make inferences about several things, including the referent of it and the sense of off which Beth intends. On the interpretation we have in mind here, Andy will take it to refer to the available milk which Beth might have added to her coffee and off to mean 'not fresh'. He will also have to infer that off means too far from freshness for Beth to consume it (we'll represent this here with a numerical subscript as $\mathrm{OFF}_{1}$ ). So one explicature of Beth's utterance might be informally represented as (2):

(2) Explicature of Beth's utterance in (1):

The milk in Andy and Beth's fridge has become too $\mathrm{OFF}_{1}$ (= 'sour') for Beth to drink it in Beth's coffee

Key features of this explicature for relevance theorists include that it is inferred according to pragmatic principles and that there is more to working it out than simply disambiguation (of off) and reference assignment (to it). We also need to make an inference about how 'off' the milk is, among other things.

Implicatures of Beth's utterance might include the following:

(3) Implicatures of Beth's utterance in (1):

a. Beth is not having milk in her coffee because the only available milk has become too sour for Beth to drink it in Beth's coffee

b. Beth wishes she had known the milk was sour before she'd made the coffee

c. Beth is unhappy that the milk is off

Some of these are more likely than others and of course we can imagine others which would arise depending on the accessibility of particular contextual assumptions (e.g. Beth might be implicating negative conclusions about Andy if she considers him responsible for the absence of fresh milk in some way). The key thing for the explicature-implicature distinction is that these are derived not by 'fleshing out' the linguistically encoded 'semantic representation'. Rather, they are derived through the interaction of explicatures (which are fleshed-out semantic representations) and independently accessed contextual assumptions.

There has been considerable discussion of the explicature-implicature distinction, with other theorists suggesting different ways of dividing up what is communicated by utterances, and debates about how exactly to define the term 'explicature' (for discussion, see CARSTON; HALL, 2012; CARSTON, 2002, 2004, 2008, 2010), We refer to these uncertainties again in section 4 where we consider their implications for our central question. For now, though, our aim is simply to present the distinction so that it is clear what kind of claim we would be making if we claimed that pictures have explicatures. 
Given the pragmatic inference involved in arriving at the explicature in (2), we can see that this proposition was not wholly explicit. We can also compare different possible utterances to show that explicatures can be more or less explicit. Consider the range of possible utterances in (4):

(4) Possible utterances:
a. It's off.
b. The milk's off.
c. The only milk we had left in the fridge this morning has gone off so I don't want to drink it in my coffee

(4b) is more explicit (requires less pragmatic inferencing to recover the explicature suggested above) than (4a) and (4c) is more explicit (requires less inferencing to recover the same explicature) than (4b).

When we discuss the interpretation of pictures in section 4, we will consider the extent to which we might think of contributions to interpretations of them as being more or less 'explicit' in a similar way.

\subsection{HIGHER-LEVEL EXPLICATURES}

Strictly speaking, Beth's utterance in (2) does not simply communicate that the milk is off; it also communicates Beth's belief that the milk is off. We might represent this as follows:

(5) Beth is expressing Beth's belief that

The milk in Andy and Beth's fridge has become

too sour for Beth to drink it in Beth's coffee

We can imagine further levels of embedding. Suppose that Andy is involved in the following exchange some time after the exchange in (2):

(6) Carol: What did Beth say was wrong with the milk?

Andy: It's off.

Here, Andy might be understood as communicating the following:

(7) Andy is expressing Andy's belief that

Beth expressed Beth's belief that

The milk in Andy and Beth's fridge has become

too sour for Beth to drink it in Beth's coffee 
To capture the notion that explicatures can be embedded within other explicatures, Sperber and Wilson (1986, p. 224-254; WILSON; SPERBER, 1988, 1993; see also CARSTON, 2002, p. 116-134; CLARK, 2013, p. 157-215) proposed the notion of 'higher-level explicatures', which are explicatures containing other explicatures within them. This notion has played a key role in accounting for a number of aspects of verbal communication, including reported speech and thought, irony, and semantic analyses of particular linguistic expressions.

In section 4, we consider the extent to which different kinds of conclusions communicated by pictures share properties of higher-level explicatures.

\subsection{IMPLICATIONS AND IMPLICATURES}

Both explicatures and implicatures are recovered by pragmatic inference. The key difference between them is that the process of inferring explicatures begins by accessing linguistically encoded material ('logical forms' in the terms used in the quote above). Implicatures, by contrast are derived from the interaction of explicatures with independently accessed contextual assumptions. Returning to the implicatures in (3), (3a) is derived by combining the assumption that Beth will not drink milk which has gone sour to a certain extent with the explicature in (2) (that the milk in Andy and Beth's fridge has become too sour for Beth to drink it in her coffee). (3b) follows from the explicature (3a) and other assumptions about Beth liking milk in her coffee, probably having looked forward to a cup of coffee with milk when she started making it, and so on. (3c) follows from the implicature (3a), (3b), and other assumptions. The key point about (3a-c) is that they are derived independently from the explicature.

Not every assumption which can be inferred from Beth's utterance will count as an explicature or an implicature. There are some assumptions which follow from Beth's utterance but which it would not be rational to assume that she intends to communicate here, e.g. that Beth is alive, that she has not lost her voice, and so on. There may also be assumptions which are relevant to Andy which he infers but does not attribute to Beth. Suppose, for example, that Andy was about to buy milk on his way home the previous evening but decided not to because he thought the milk at home would probably be OK. He can now infer (8):

(8) Beth would not be upset about the milk if Andy had bought the milk he had thought about buying last night.

Andy cannot believe that Beth intended him to infer this because she cannot have known that he almost bought milk the night before. This is an implication of Beth's utterance but not an implicature. One way of describing the task of hearers or viewers in understanding utterances is to say that they aim to work out implicatures of the communicative act. Another is to say that the task is to identify from all of the implications of the act those ones which are intentionally communicated, i.e. implicated. 


\subsection{STRONGER AND WEAKER EXPLICATURES AND IMPLICATURES}

A property which is shared by explicatures and implicatures is that they can be more or less strongly communicated. We saw in 2.2 above that explicatures can be more or less explicit. We can also be more or less sure that a particular explicature is being communicated.

One way to demonstrate this is to consider how the evidence available to the speaker for particular explicatures and implicatures might vary. Consider, for example, Beth's response here:

(9) Andy: How are you getting on with your new flatmate?

Beth: Well, he's ... [sighs]

Here, Beth has ostensively paused and then failed to complete her utterance and sighed. This suggests that she is struggling to express what she thinks of her new flatmate. We can rule out certain straightforwardly positive propositions which she might have communicated (such as that her new flatmate is fun or easy to get along with). We cannot, however, decide that she intended any specific proposition, such as that Beth's new flatmate is not as easy to get on with as Beth would like, that her new flatmate is irritating, and so on. Rather, Beth's utterance has provided some evidence that she might intend to communicate propositions like these but not strong evidence for any of them.

Given the uncertainty about how strongly Beth intends to communicate each of these explicatures, any implicatures which follow from the interaction of these with other assumptions will also be relatively weakly communicated, e.g. that Beth wishes her new flatmate was easier to get on with, was less irritating, and so on. We have more evidence for the assumption that Beth is not sure how she feels about her new flatmate.

There has been more discussion of varying strength of implicatures than of explicatures. Arguably, this is because variation in strength of implicatures is more often exploited for particular effects and because varying strength of implicatures is more salient in many contexts. Even a fairly straightforward utterance such as Beth's response in (10) provides evidence for more than the most obvious explicature and implicature:

(10) Andy: I've got a spare ticket for the game on Saturday. Do you fancy coming?

Beth: I'm not into football.

The strongest implicatures of Beth's utterance here are (11a-b):

(11)a. Beth does not fancy coming to the game on Saturday.

b. The reason Beth does not fancy coming to the game on Saturday

is because she is not interested in football. 
Beth's utterance also gives some evidence for a range of other conclusions, such as those in (12):

(12)a. Beth does not want to go to any other football game.

b. Beth does not want to watch football on TV.

c. Beth is not interested in sport in general.

d. Beth is not interested in rugby.

e. Beth is not interested in basketball.

f. Beth has a negative attitude to Andy's interest in football.

Beth has not provided conclusive evidence for any of the conclusions in (12) and she has definitely provided less evidence for them than for (11a-b). Andy cannot be sure that she intended any of them. He has quite strong evidence for (12a-b) but less evidence for each of (12c-f). Nevertheless, Beth has provided some evidence for each of them and Andy can think further about them if he chooses to. The varying strength of implicatures has been much discussed in previous work and plays a key role in accounts of 'poetic' and literary language. It has been suggested that some utterances achieve relevance by giving rise to a wide range of relatively weakly communicated implicatures rather than a small set of stronger ones (see PILKINGTON, 2000 for discussion).

\subsection{ARE THERE NON-LINGUISTIC EXPLICATURES?}

If we accept that explicatures require linguistic encoding, then it would follow that pictures without a textual element can give rise only to implications and implicatures. In the next section, we consider two kinds of encoding which do not involve linguistic material: coded nonverbal behaviours as discussed by Wharton (2009) and pictorial codes as discussed by Forceville (2011; FORCEVILLE et al 2014). After that, in section 4 , we consider whether the processes involved in understanding noncoded elements in pictures can be differentiated from each other in ways which echo differences among processes involved in understanding verbal communication. In particular, some of the processes seem to resemble the processes involved in deriving explicatures (i.e. fleshing out logical forms, even though these are not derived from linguistic or non-linguistic coding). In the rest of this paper, we consider arguments for and against recognising something 'explicature-like' in the comprehension of pictures and perhaps even extending the term 'explicature' to the interpretation of (parts of) pictures.

\section{NONVERBAL AND PICTORIAL CODES}

In this section, we consider some varieties of coded nonverbal behaviour discussed by Wharton (2009) and pictorial codes discussed by Forceville (2011, FORCEVILLE et al., 2014). When these phenomena appear in ostensive pictures, what they encode is inferentially enriched in order to arrive at a fuller interpretation, a 
property they share with explicatures derived on the basis of linguistically encoded material. We briefly discuss how visuals and language can combine to give rise to explicature-like inferences.

\subsection{NONVERBAL CODES}

Wharton (2009) provides the fullest discussion so far of nonverbal communication from the perspective of relevance theory. While many instances of nonverbal communication fit the default assumption that all the propositions they communicate are implicatures, some nonverbal behaviours can be understood as having coded meanings. Wharton (2009) discusses a range of possibilities and proposes a number of notions and distinctions which help to account for what is communicated by nonverbal behaviour.

Building on the work of a range of previous researchers from a variety of approaches, Wharton (2009, p. 107-138) distinguishes signs from signals, each of which can be seen as 'natural' or 'non-natural' in a sense derived from Grice's (1957) discussion of 'meaning'. He adopts Hauser's (1996) distinction between natural signs (which do not have a primarily communicative function) and natural signals (which have evolved primarily to communicate). A natural sign in the animal world is the presence of chimpanzee nests which forest monkeys use to avoid their chimpanzee predators. The cries of vervet monkeys when noticing specific predators, by contrast, are natural signals which have evolved with the precise function of warning other vervet monkeys of the presence of specific predators. Wharton illustrates the sign-signal distinction for humans by considering shivering and smiling. Shivering has evolved as a response to cold and not in order to communicate that someone is feeling cold. Smiling, by contrast, has evolved precisely in order to communicate a mental state. These distinctions are related to what Wharton (2009) terms the 'showing-meaning ${ }_{\mathrm{NN}}$ continuum':

\section{Overt communication and the showing-meaning $_{\mathrm{NN}}$ continuum}

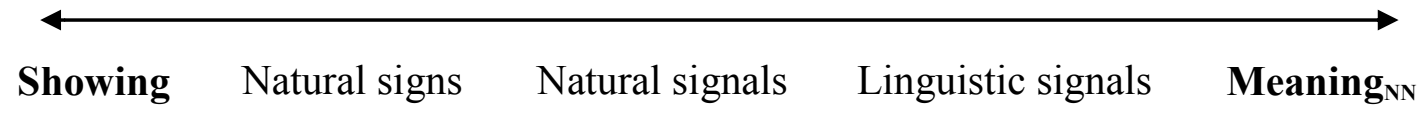

This continuum represents a long-standing assumption of relevance theory (see, for example, Sperber and Wilson 1995, p. 50-54) that there is no clear-cut distinction between cases of showing, where meanings are inferred on the basis of non-encoded evidence, and cases of what Grice termed 'non-natural meaning' or 'meaning ${ }_{\mathrm{NN}}$ '. Wharton (2003a, 2003b) used this notion in arguing that spontaneously produced natural signs and signals are located along this continuum and fall within the domain of pragmatics.

Wharton (2009, p. 149) also considers gestures, showing that

communicators have a whole range of gestures at their disposal. At one extreme, there are the entirely natural, non-linguistic gesticulations that are spontaneously used to accompany speech. At the other, there is sign language proper, which is fully linguistic and non-natural in Grice's sense. 
Wharton also discusses culture-specific 'emblems' (EKMAN; FRIESEN, 1969), such as the 'thumbs-up' and 'thumbs-down' gestures, two raised fingers, etc., which 'whilst clearly non-linguistic, are equally clearly non-natural in Grice's sense' (WHARTON, 2009, p. 149; for discussion of gestures accompanying words in utterances, see de BRABANTER, 2010). Clearly, when we process non-natural coded behaviour, whether in pictures or elsewhere, the coded material is inferentially fleshed out to arrive at an interpretation. Wharton (2009, p. 115) points out that this applies equally to ostensively used natural coded behaviours:

[...] when natural coded behaviours are put to use in ostensive-inferential communication, the automatic decoding processes that govern their interpretation are supplemented by other equally specialised automatic — but this time inferential—processes that govern the interpretation of ostensive stimuli.

The vital point here is that nonverbal behaviours can present coded material which is inferentially enriched in an 'explicature-like' way. These inferential enrichment processes will of course occur when such behaviours are represented in ostensive pictures.

\subsection{PICTORIAL CODES}

Since pictures don't have a grammar (pace KRESS; van LEEUWEN, 2006 [1996]) and a vocabulary, they would seem to be incapable of transmitting 'coded' information. But there are at least two reasons to think that this is too hasty a conclusion. First, as Roland Barthes pointed out in the heyday of structuralism, interpreting pictures requires cultural knowledge of the viewer, who needs to be in possession of certain 'lexicons' (1986, p. 35) to be successful. Incidentally, Barthes routinely discusses the interpretation of pictures in terms of drawing on a 'code' (using a different use of the word 'code' from the one we are adopting here). A second reason not to leap to an outright rejection of the notion of visual 'codes' is that pictures, or rather 'visuals' do not constitute one monolithic category. There are several categories of pictorial elements that have such a precise meaning that their interpretation is surely not a matter only of inferencing but must also include an element of coding. In this section, we briefly discuss several of them.

First, consider pictograms, which can be defined as 'stylized depictions of phenomena that are familiar from real-life phenomena or from other visual genres, but that often have acquired a more or less conventional meaning' (FORCEVILLE et al., 2014, p. 492). They are particularly prevalent in comics but are also used as signs to aid navigation in public buildings (see figure 1). A thesaurus could be compiled of them, providing a more or less fixed meaning for each item (GASCA; GUBERN, 2001). Other pictorial elements in comics that arguably qualify as visual information that is to be decoded rather than inferred are movement and emotion lines, and text balloons (see FORCEVILLE et al., 2010). 
Figure 1: Pictograms and coded signs for 'bright idea', 'music', 'play', and 'exit'2
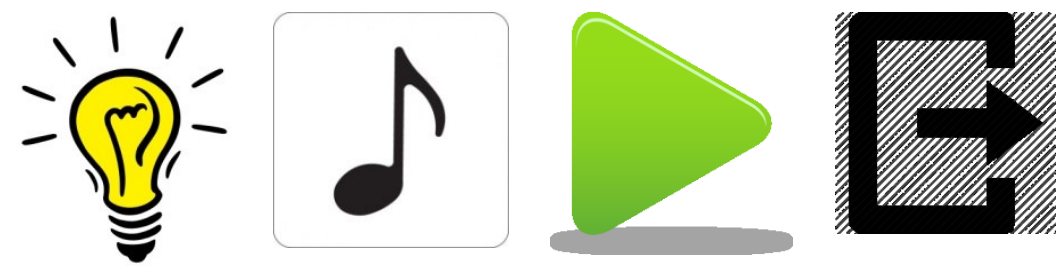

A second group of visual elements which can be understood to have an element of coding are (brand) logos. Logos may combine visual and verbal elements, or be completely visual. Even logos that might seem to be primarily verbal have always been designed in terms of font, size, colour, etc., and therefore always have visual aspects. The logos of strong, international brands can be recognised without an accompanying brand name (see figure 3).

Figure 2: Brand logos for Pepsi, Nike, McDonalds, and Shell ${ }^{3}$
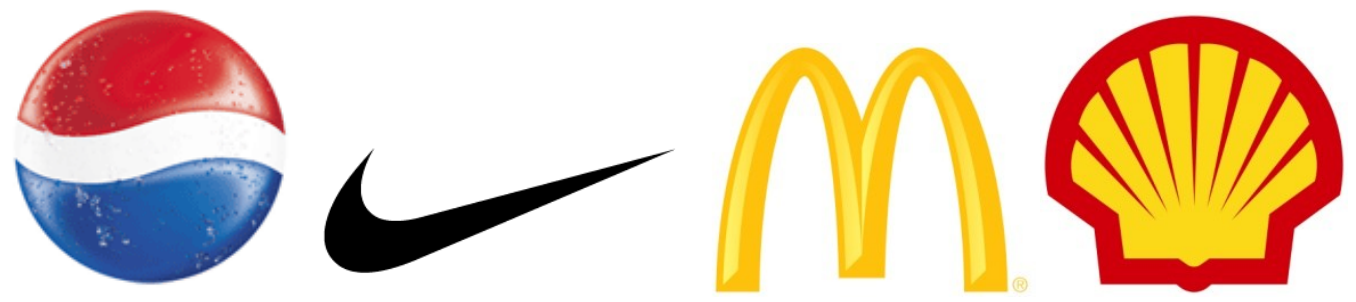

A third category of 'coded' visual information is illustrated by stylized 'signs', such as traffic signs. Again, you need to know the code, and if you do, you understand the relatively precise and limited meaning of the sign. We come across numerous such signs on our electronic equipment (smartphones, ipads, DVD players etc.). An interesting feature of the coded nature of these signs is that they allow for a rudimentary degree of combinability (and thus can be argued to feature elements of a kind of 'grammar'). Figure 3 provides an example:

Figure 3: Coded signs allow for a basic degree of combinability ${ }^{4}$

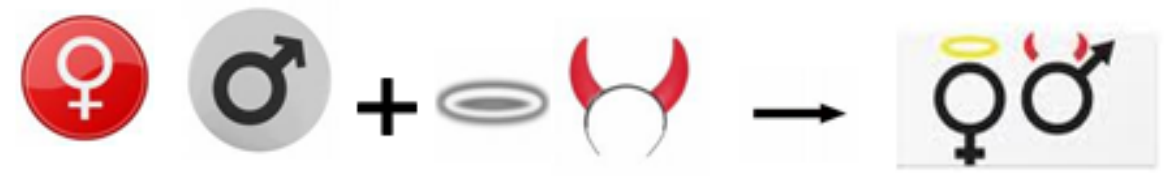

\footnotetext{
${ }^{2}$ Originals partly in colour.

${ }^{3}$ Originals partly in colour.

${ }^{4}$ Originals partly in colour.
} 
A fourth category is that of symbols used on maps, diagrams, and other forms of graphics. Often these symbols are stylized versions of the objects they refer to, so that one might easily guess what they stand for. In other cases, one would need to know the code (see ENGELHARDT, 2002).

In short, there are at least some categories of visuals that resemble language in having a coded component. Understanding them involves less inferencing than is required for other kinds of visual material. This also means that, while realistic visuals usually provide some information because of their resemblance to what they depict, these coded visuals can only be deciphered by those who possess the code-very much as in language.

Wharton's (2003a, 2003b, 2009) discussion of a 'showing-meaning continuum' seems particularly useful here. Pictograms provide evidence of communicative intentions which is more direct, or more 'natural', than the evidence provided by words. Examples such as these can be seen as useful data for exploring further the notion of a showing-meaning continuum at the same time as benefitting from the analytical possibilities it provides.

In this section, then, we have identified a number of nonverbal phenomena which can be understood to contain an element of coding and to provide input to inferential processes.

\subsection{CODED ELEMENTS ACCOMPANYING OSTENSIVE PICTURES}

As has been frequently discussed, visual and verbal material often accompany each other and interact in communicating particular assumptions. A positive verbal comment (e.g. 'together at last') might push the interpretation of an image in one direction while a negative comment (e.g. 'I still can't shake him!') might have the opposite effect. Clearly, similar effects can be achieved with coded nonverbal material (e.g. a 'thumbs-up' or 'thumbs-down' icon accompanying a text message or social media update). A simple example of a 'text' in which picture and language necessarily complement each other can be found in your passport: both the photograph and your name are minimally required to identify you (BARTHES calls this 'relay', 1986, p. 28). Another example is that many captions accompanying news photographs and pictures in manuals combine to achieve relevance. Other varieties include the use of deixis that needs to be understood in conjunction with a picture (e.g., 'this is what the symptoms of measles look like'). Photographs and comics panels, among others, may also contain verbal text in the picture itself, which helps to identify specific locations and buildings. The visual design of the letters may play a role here too: the way the word 'saloon' in a Lucky Luke panel has been painted is different from the stone-hewn 'mea requies' in an Asterix panel. The relationships between words and pictures - the most common combination of modes discussed in the quickly growing discipline of 'multimodality' (see JEWITT, 2013)—are manifold, and heavily undertheorized; see Bateman (2014) for an overview. 
In this section, we consider the extent to which we can say that non-coded elements of ostensive pictures give rise to 'explicature-like' communicated assumptions. We suggest that some of these can be understood as more 'explicaturelike' than others while some are clearly implicatures.

\subsection{POTENTIAL EVIDENCE FOR EXPLICATURES IN OSTENSIVE PICTURES}

So far we have seen that verbal communication gives rise to explicatures. Let us now consider whether it makes sense to extend the notion to some varieties of noncoded nonverbal discourse. Here we consider whether anything like the explicatureimplicature distinction seems to exist in ostensive pictures. We begin by considering a cartoon by David Suter (figure 4).

\section{Figure 4: Cartoon by David Suter}

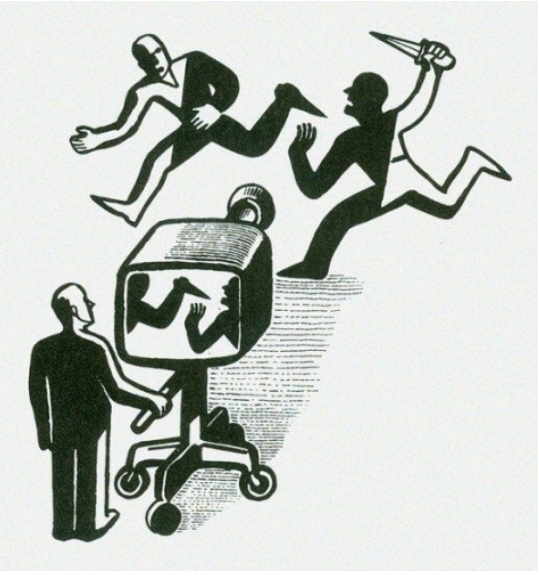

Some central things which we assume most viewers will conclude from this image if they were asked to paraphrase it are listed in (13):

(13) Central things:

a. A man is operating a camera which is pointed at two other men.

b. The man being filmed who is on our right is attacking the man being filmed who is on our left.

c. The camera is capturing only part of what is happening in front of it.

d. The camera operator believes that [13b]

e. The image in the camera suggests that the man being attacked is the attacker and that the man who is attacking is the one being attacked.

f. Viewers who see only a version of the image in the camera will believe that the man being attacked is the attacker and vice versa.

g. These viewers will be misinformed about what is happening.

h. (The cartoon as a whole represents the idea that) we can be misinformed if we only see part of an event.

i. (The cartoon as a whole represents the idea that) images can be misleading. 
Explaining how we arrive at these will involve accounts of more specific conclusions about what particular parts of the picture represent. A fuller account will also need to account for further assumptions we might infer, e.g. about what we can trust more generally. We have listed these as a starting point and now consider the questions raised in section 2 above.

\subsection{1 'EXPLICATURE-LIKE' AND 'IMPLICATURE-LIKE' ASSUMPTIONS}

It seems clear that some of the assumptions in (13) seem to be more like explicatures than others and that some of them seem to be implicatures. (13a) seems to be inferred by 'fleshing out' a representation of the shapes, and thus is more 'explicature-like', while (13f-g) seem to depend on assumptions about the world interacting with a representation of what the whole image represents, and thus are more 'implicature-like'.

\subsection{2 'DEGREES OF EXPLICITNESS'}

To say that some of the assumptions communicated by the picture are more like explicatures than others can be understood as saying that some are more explicit than others. Here we need to include some assumptions we did not list in (13) above. In order to arrive at (13a) we need to infer the conclusions in (14):

(14) Conclusions:
a. The figure in the foreground is a man.
b. The object next to this man is a camera.
c. The man's hand is on the camera.
d. The man is operating a camera which is filming the men in the background.

If 'less explicit' means 'requires more inferencing', then we can say that (13a) is less explicit than each of these (and we could describe a similar set which are involved in arriving at (13b). We might also say that visual representations of a particular object can be more or less explicit. A drawing can for instance depict a house with a few lines, or in a highly detailed manner.

\subsection{3 'HIGHER-LEVEL EXPLICATURES'}

We might think of the relationship between (13a) and the assumptions in (14) as similar to the relationship between explicatures at different levels. Perhaps a clearer example, though, is the relationship between (13b) and (13d). (13d) is an assumption about what the camera operators believes and contains (13b) as a sub-part. 
This is perhaps the easiest of our questions to answer. Any act of ostensive communication provides evidence for a vast number of conclusions, only some of which are taken to be communicated. (13h) and (13i) are clearly intended implicatures of the picture - given our knowledge of the conventions of the cartoon genre-needing to be inferred for the picture to achieve relevance. Most viewers are likely to infer these (as evidence, many representations of this image on the internet are accompanied by the text 'The TV shows you what they want you to see'). Mere implications of the picture which we are not likely to attribute to Suter include (15a-b):

a. There are fewer than ten people represented in the picture.

b. The artist (or artists if the viewer does not know about who made the picture) was alive when he/she/they made the picture.

\subsubsection{STRONGER AND WEAKER COMMUNICATION}

The fact that communicated assumptions can be more strongly or more weakly communicated is related to the fact that some conclusions which follow from an act of communication are not assumed to be communicated. Implications are at one end of a continuum with very strongly communicated assumptions at the other end. Here are some implicatures which are less strongly communicated than (13h-i):

(16)
a. We should not trust all/any information from media sources.
b. We should not trust all/any information we do not find directly for ourselves.
c. We should not trust what other people tell us.

The picture provides some evidence for each of these but we cannot be certain that Suter intended us to derive any one of them in particular. He has some responsibility for us deriving them, though, and so they are implicatures which are weaker than (13h-i).

\subsubsection{MUTUAL PARALLEL ADJUSTMENT PROCESSES}

Relevance theory sees the processes of interpreting ostensive stimuli as working in parallel and mutually adjusting each other. Hypotheses about possible explicatures (including disambiguation, reference assignment, etc.) influence hypotheses about possible implicated premises and conclusions and so on.

One crucial difference in the mutual parallel adjustment processes when interpreting still images is that all of the evidence provided by the picture is available at 
once. When understanding speech or moving images, we access evidence as it becomes available. While 'scanning' a picture takes time, the whole picture appears at once in our visual field and all parts of it are available to our attention at once. With a spoken utterance, we may begin to form hypotheses about speakers' intended meanings as soon as they begin to speak and then adjust our assumptions when we hear later parts of the utterance. With a picture, the whole image is available at once. The adjustment process may involve making initial hypotheses based on attention to specific parts and adjustment when we notice other parts. At the same time, the genre to which a picture belongs (which we often know before we start looking at it) and elements such as colouring, size, lighting etc. guide our attention. Eye-tracking experiments confirm that 'in a study of picture viewing, picture description and mental imagery, a significant similarity was found between (a) the eye movement patterns during picture viewing and (b) those produced during picture description when the picture was removed and the informants were looking at a white screen' (HOLŠÁNOVÁ, 2008, p. 177; see also SMITH, 2013).

\subsection{FURTHER EXAMPLES}

We have discussed pictures in which explicatures are associated with linguistic material, visual codes and pictorial codes, and we have pointed out that communicated assumptions derived from other material also seem to vary in ways which echo the explicature-implicature distinction; that pictures also give rise to implications and implicatures; that assumptions can be communicated more or less strongly; that understanding pictures, in line with all ostensive communication, involves mutual adjustment processes; and that there is one key difference with pictures in that the whole picture is presented at once rather than as a stream of sound or a sequence of printed words and punctuation marks. However, visual processing might not be as different as this suggests, since even 'scanning' static pictures takes time. To begin to address more fully the complexity of how pictures communicate, we now consider two other images and how we might account for what they convey.

Figure 5: Panel from Asterix and the Roman Agent ${ }^{5}$

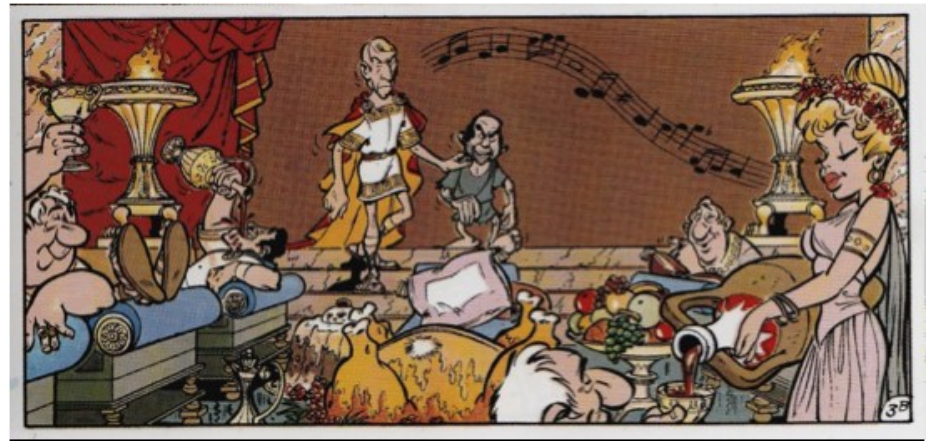

\footnotetext{
${ }^{5}$ Original in colour.
} 
The panel in Figure 5 is the $25^{\text {th }}$ in the album Asterix and the Roman Agent, and the first that has no verbal component. Unlike the Suter cartoon, which is a standalone picture, this panel is one that a viewer/reader typically comes across after having accessed the previous 24 panels. Enrichment of the visual information in the panel includes what can be understood as a form of reference assignment: the blond man with the sharp face will be understood as Julius Caesar, and the unpleasant-looking man on whose shoulder his hand rests is Tortuous Convolvulus. Both of them have been introduced in earlier panels so there is a kind of anaphoric reference giving rise to a cohesion relation. The others are Roman senators-again, we have seen them before, although most of them have not been identified by name. The woman on the right is a (similarly generic) servant. There are no clear cases of anything resembling disambiguation, concept loosening or broadening here (as discussed by CARSTON 1997; 2002). However, we could argue that individual lines can be ambiguous in the loose sense that they could be taken to represent something else-whether trivially as to whether the lines on the floor that Caesar and Tortuous Convolvulus walk on are dark patches or demarcating borders of tiles, or critically as in the case of the foot of the man on the left in Suter's cartoon above, which resembles a hand holding a dagger when presented within the camera below. We might also suggest that every new presentation of a character adjusts our existing representation of that character. This has something in common with concept adjustment but of course we are not dealing here with lexicalised concepts. Evidently, viewers need to have, in their cognitive environment, knowledge of Roman senator orgies as well as of the comics convention to cut off parts of human bodies by panel borders. However, these conventions are not the same kinds of coded conventions associated with lexical items (where perception of a sequence which could represent a word causes access to other senses of the word regardless of context). The musical notes, contributing to the orgy scenario, are an example of coded 'pictograms'. The little lines left of both Caesar and Convolvulus help suggest that they move. Both the notes and the movement lines can be understood as encoding something. However, even if we would be prepared to accept that these elements are coded, this does not hold for other elements in the picture, so that even if we have to recruit 'lexicons' of cultural knowledge to interpret the picture as a whole - as Barthes claims - it would be difficult to claim that we 'decode' the picture. Understanding of these elements is not acquired in the same way as lexical word meanings and there is more scope for individual variation than with linguistic material.

An explicature-like assumption here is that 'Caesar and Tortuous Convolvulus enter the Roman senate' or, based on assumptions derived from reading previous panels, a more precise assumption such as that 'Caesar introduces Tortuous Convolvulus to the Roman senators'. This is the most relevant information in the picture for the reader at this point in the story. Other explicature-like assumptions are not required in order to follow the plot of the story, e.g. 'the senators are heavily eating and drinking', 'the man in the foreground has white hair', or 'there is a pink cushion in the centre of the panel'. Implicatures of the picture might include that 'the senators may be in for a surprise when confronted with this unseemly man as Caesar's candidate for beating the Gauls'. 
Figure 6: A beach scene, retrieved from internet searching for "holiday pictures"6

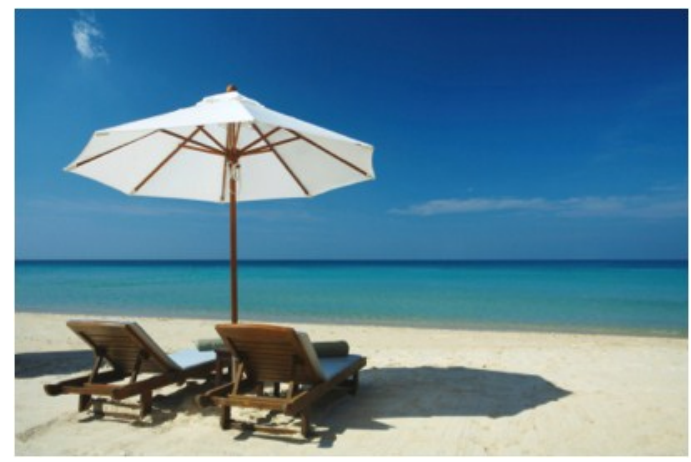

Now consider figure 6, which has no accompanying verbal material and which we present here with very limited contextual information. The knowledge in their cognitive environment reliably allows most people to infer that what is depicted is two deck chairs on either side of a parasol, on a sunny beach, next to water, under a blue sky. But what assumptions does it communicate? As long as we do not know about the genre the photograph belongs to, this is a somewhat hazardous affair. Let us assume that we came across this picture in a travel agent's holiday brochure. In this case the interpretation would be something as vague as 'This is an enticing place to spend one's holiday'. But in the promotion brochure of a department store, it might be slightly different: 'These deckchairs and parasol for sale with us, for a true sense of holiday'. And in an instruction leaflet for beach workers renting out such sets, the interpretation might be, 'This is how the deckchairs and the parasol are to be set up'. Interestingly, commercial image banks deliberately aim for this kind of ambiguity, so as to attract as many buyers as possible, each with their own context in which to embed the stock image (MACHIN, 2004). Lack of space prevents us from further discussing the pertinent issue of whether these interpretations should be considered explicatures or implicatures.

\subsection{SO ARE THERE PICTORIAL EXPLICATURES?}

We have considered the option that communicated developments of visual material, including material based on pictorial codes, can be considered as explicatures, i.e. that explicatures can be derived on the basis of some non-linguistic as well as linguistic stimuli. While we have not here proposed to use the term 'explicature', we have identified a number of other kinds of communicated assumptions which share properties of explicatures in that they involve processes such as reference assignment, are derived by 'fleshing out' representations rather than combining communicated assumptions with contextual assumptions, and seem to be distinguishable from assumptions which seem clearly to be implicatures. While we do not draw a conclusion here, we list some arguments for and against using the term 'explicature' to describe them.

\footnotetext{
${ }^{6}$ Accessed on 17 feb. 2014. Original in colour.
} 


\subsubsection{ARGUMENTS FOR EXTENDING USE OF THE TERM 'EXPLICATURE’}

Here are arguments we can think of now for extending use of the term to assumptions communicated by pictures which are not clearly linked to coded material.

a) Understanding pictures requires knowledge of conventions of depiction as well as of genres that, even though pictures do not have a grammar or a vocabulary, suggest that we should broaden the concept of 'encoding/decoding'.

b) Even though there may be disagreement about the precise verbalization of the relevant information inhering in a picture, it is in most types of pictures uncontroversially clear what explicit information is conveyed.

c) Pictures give rise to assumptions which differ in that some are more 'explicature-like' and some are more 'implicature-like'.

d) Deriving these assumptions includes processes which resemble disambiguation, reference assignment and other kinds of enrichment processes.

e) It is not always easy to draw a clear distinction between explicature and implicature (for discussion, see CARSTON; HALL, 2012; CARSTON, 2002, 2004, 2008, 2010). Arguably, one reason for this difficulty is the nature of the mutual parallel processing involved in understanding ostensive communication. In real time interpretations, we might arrive at conclusions about what a communicator might want to communicate even before an ostensive act begins.

This last point might suggest that agreeing on the exact reach of the term is less important than might otherwise be supposed. At the same time, of course, it might suggest that it is more advisable simply to focus on how pictures communicate than on this terminological issue. We have two reasons to think it is worthwhile to treat this question as more than merely terminological. First, our discussion has helped us to think about how pictures communicate. Second, the difficulty of defining the term in practice does not rule out its theoretical usefulness. We might never actually create representations only of what is linguistically encoded ('semantic representations') but it is still theoretically useful to describe what is encoded by particular linguistic expressions.

\subsubsection{ARGUMENTS AGAINST EXTENDING USE OF THE TERM 'EXPLICATURE’}

Here are arguments we can think of against extending the use of the term 'explicature' to these communicated assumptions.

a) Absence of encoded meanings. The assumptions we are considering here are not derived on the basis of encoded meaning of the type associated with linguistic expressions. We might argue that there are looser associations with particular kinds of communicated assumptions but nothing as direct or 
automatic as what is associated with linguistic expressions. This would entail rejecting the use of the term 'code' as used by Barthes (and many other structuralists) as being misleading.

b) Theoretical simplicity. Restricting the term 'explicature' to assumptions derived from linguistically encoded meanings is a clear-cut and easily understood decision. Extending it like this makes it harder to see exactly what is encompassed by the term. This move might be seen as moving from an understanding of the definition of 'explicature' with clear theoretical boundaries to one where the term is less definable than before. Arguably, it makes sense to add complexity to a theoretical framework only when this is unavoidable.

\section{CONCLUSIONS}

While pictures communicate in a way that is fundamentally different from language, pictures clearly can contain explicit information which can originate in both linguistically and non-linguistically encoded material. Other elements of pictures also give rise to communicated assumptions which share properties of explicatures to some degree. At this stage we suspend judgment as to whether these assumptions should be described as 'explicatures', as this question has consequences for terminological definitions that require extended discussion and exploration. Clearly, more research needs to be done on the principles underlying the internal structure of pictures. A further step would be to investigate how modes such as ostensive non-verbal sound, music (e.g., in film), and even touch, smell, and taste can be accommodated within the relevance-theoretic approach we have adopted here. This research will help further develop the notion of ostensive communication in relevance theory and provide tools to analyse non-verbal and multimodal communication in general.

\section{REFERENCES}

BARTHES, R. Rhetoric of the Image. In: Oxford: Blackwell, 1986 [1964]. p. 21-40. . The Responsibility of Forms. Translated by R. Howard. BATEMAN, J. Text and Image: A Critical Introduction to the Visual/Verbal Divide. London: Routledge, 2014.

De BRABANTER, P. Uttering Sentences Made Up of Words and Gestures. In: SORIA, B.; ROMERO, E. (Eds.). Explicit Communication: Robyn Carston's Pragmatics. Basingstoke: Palgrave MacMillan, 2010. p. 199-216.

CARSTON, R. Enrichment and Loosening: Complementary Processes in Deriving the Proposition expressed? Linguistische Berichte 8, Special Issue on Pragmatics, 1997, p. 103-127.

Thoughts and Utterances: The Pragmatics of Explicit Communication. Oxford: Blackwell, 2002. Relevance Theory and the Saying/Implicating Distinction. In: HORN, L.; WARD, G. (Eds.). The Handbook of Pragmatics. Oxford: Blackwell, 2004. p. 633-656. $\overline{321-345}$.

Linguistic Communication and the Semantics-Pragmatics Distinction. Synthese, v. 165, 2008, p. 
Explicit Communication and 'Free' Pragmatic Enrichment. In: SORIA, B.; ROMERO, E. (Eds.). Explicit Communication: Robyn Carston’s Pragmatics. Basingstoke: Palgrave MacMillan, 2010. p. $217-$ 285.

; HALL, A. Implicature and explicature. In: SCHMID, Hans-Joerg (Ed.). Cognitive Pragmatics. V. 4. Berlin: Mouton de Gruyter, 2012. p. 47-84.

CLARK, B. Relevance Theory. Cambridge: Cambridge University Press, 2013.

EKMAN, P.; v. FRIESEN, W. The Repertoire of Non-Verbal Behaviour Categories: Origins, Usage and Coding. Semiotica, v. 1, 1969, p. 49-98.

ENGELHARDT, Y. The Language of Graphics: A Framework for the Analysis of Syntax and Meaning in Maps, Charts and Diagrams. Amsterdam: University of Amsterdam, Institute for Logic, Language and Computation, 2002.

FORCEVILLE, C. Pictorial Metaphor in Advertising. London: Routledge, 1996.

Addressing an Audience: Time, Place, and Genre in Peter van Straaten's Calendar

Cartoons. Humor: International Journal of Humor Research, v. 18, 2005, p. 247-278.

. Relevanz und Prägnanz: Kunst als Kommunikation. Translated by Martina

Plümacher. Zeitschrift für Semiotik, v. 31, 2009, p. 31-63.

Pictorial Runes in Tintin and the Picaros. Journal of Pragmatics, v. 43, 2011, p. 875-890.

Relevance Theory as Model for Analysing Visual and Multimodal Communication. In:

MACHIN, D. (Ed.), Visual Communication. Berlin: Mouton de Gruyter, 2014. p. 51-70.

; el REFAIE, E.; MEESTERS, G. Stylistics and Comics. In: BURKE, M. (Ed.). Routledge Handbook of Stylistics. London: Routledge, 2014. p. 485-499.

GASCA, L.; GUBERN, R. El discurso del comic. Madrid: Catedra, 2001 [1994].

GRICE, H. P. Meaning. The Philosophical Review, v. 66, 1957, p. 377-388.

HAUSER, M. The Evolution of Communication. Cambridge: Cambridge University Press, 1996.

HOLŠÁNOVÁ, J. Discourse, Vision and Cognition. Amsterdam: Benjamins. 2008.

JEWITT, C. (Ed.). The Routledge Handbook of Multimodal Analysis. 2nd. ed. London: Routledge, 2013.

KRESS, G.; van LEEUWEN, T. Reading Images: The Grammar of Visual Design. 2nd ed. London: Routledge, 2006 [1996].

MACHIN, D. Building the World's Visual Language: the Increasing Global Importance of Image Banks in Corporate Media. Visual communication, v. 3, 2004, p. 316-336.

PILKINGTON, A. Poetic Effects. Amsterdam: John Benjamins, 2000.

SMITH, T.J. Watching you Watch Movies: Using Eye Tracking to Inform Film Theory. In:

SHIMAMURA, A. P. (Ed.). Psychocinematics: Exploring Cognition at the Movies. Oxford: Oxford University Press, 2013. p. 165-191.

SPERBER, D.; WILSON, D. Relevance Theory. 2nd ed. Oxford: Blackwell, 1995 [1986].

WHARTON, T. Natural Pragmatics and Natural Codes. Mind and Language, v. 18, 2003a, p. 447-477.

Interjections, Language and the 'Showing-Saying' Continuum. Pragmatics and Cognition, v. 11, 2003b, p. 39-91.

Pragmatics and Non-Verbal Communication. Cambridge: Cambridge University Press, 2009.

WILSON, D.; SPERBER, D. Relevance Theory. In: HORN, L.; WARD, G. (Eds.). The Handbook of Pragmatics. Oxford: Blackwell, 2004. p. 607-631.

; _. Meaning and Relevance. Cambridge: Cambridge University Press, 2012.

; WHARTON, T. Relevance and Prosody. Journal of Pragmatics, v. 38, 2006, p. 1559-1779.

YUS, F. Inferring from Comics: a Multi-Stage Account. In: CREMADES, P. S.; SIGNES, C. G.;

RENARD, S. (Eds.). El discurs del comic. Valencia: University of Valencia, 2008. p. 223-249.

Visual Metaphor versus Verbal Metaphor: a Unified Account. In: FORCEVILLE, C.; URIOS-

APARISI, E. (Eds.). Multimodal Metaphor. Berlin: Mouton de Gruyter, 2009. p. 147-172. 
Título: As imagens podem ter explicaturas?

Autores: Charles Forceville e Billy Clark

Resumo: Este artigo avalia se as imagens podem ser entendidas como geradoras de significados explícitos. Em termos da Teoria da Relevância, isso significa perguntar se as imagens dão origem a 'explicaturas'. A definição do termo "explicatura" parece descartar essa possibilidade, exceto em casos nos quais as imagens incluem ou são acompanhadas por material com significados codificados. $O$ documento considera uma gama de fenômenos não verbais com significados codificados, incluindo pictogramas (FORCEVILLE, 2011, FORCEVILLE et al., 2014). Considera-se, então, se a distinção explicatura/implicatura poderia ser relevante para fotos sem esses elementos. Algumas suposições comunicadas por figuras parecem ser mais 'tipo-explicatura' do que outras, por isso é possivel que essa distinção seja útil. A questão não é meramente terminológica, já que a discussão leva a uma compreensão mais completa das maneiras como as imagens comunicam.

Palavras-chave: Teoria da Relevância. Imagens. Explicatura. Códigos pictóricos. Comunicação visual. Multimodalidade.

Título: ¿Pueden las imágenes tener explicaturas?

Autores: Charles Forceville y Billy Clark

Resumen: Este artículo aborda la cuestión de si las imágenes dan lugar a significados explícitos. En términos de la teoría de la relevancia, esto conlleva preguntarse si las imágenes generan "explicaturas". La definición del término "explicatura" parece descartar esta posibilidad excepto en casos en los que las imágenes incluyen o están acompañadas por elementos con significados codificados. El artículo analiza una serie de fenómenos no verbales, incluyendo los pictogramas (FORCEVILLE 2011, FORCEVILLE et al., 2014). Con posterioridad, analiza si la distinción explicatura-implicatura podría ser adecuada para imágenes que no poseen tales elementos. Algunos supuestos comunicados por las imágenes parecen ser más parecidos a una explicatura que otros, por lo que es posible que la distinción sea útil. La cuestión no es simplemente terminológica, ya que la discusión conduce a una mejor comprensión de las formas en las que las imágenes comunican.

Palabras-clave: Teoría de la relevancia. Imágenes. Explicatura. Códigos pictóricos. Comunicación visual. Multimodalidad. 